\title{
FORUM
}

Submitted 04.28.2013. Approved 01.24.2014

Evaluated by double blind review. Scientific Editors: Wesley Mendes-Da-Silva, Newton C. A. da Costa Jr, Lucas Ayres, Manuel Rocha Armada and Jill M. Norvilitis

DOI: http://dx.doi.org/10.1590/So034-759020150105

\section{ABOUT PSYCHOLOGICAL VARIABLES IN APPLICATION SCORING MODELS}

\author{
Sobre variáveis psicológicas em modelos de application scoring \\ Sobre variables psicológicas en modelos de application scoring
}

\begin{abstract}
The purpose of this study is to investigate the contribution of psychological variables and scales suggested by Economic Psychology in predicting individuals' default. Therefore, a sample of 555 individuals completed a self-completion questionnaire, which was composed of psychological variables and scales. By adopting the methodology of the logistic regression, the following psychological and behavioral characteristics were found associated with the group of individuals in default: a) negative dimensions related to money (suffering, inequality and conflict); b) high scores on the self-efficacy scale, probably indicating a greater degree of optimism and over-confidence; c) buyers classified as compulsive; $d$ ) individuals who consider it necessary to give gifts to children and friends on special dates, even though many people consider this a luxury; e) problems of self-control identified by individuals who drink an average of more than four glasses of alcoholic beverage a day.
\end{abstract}

KEYWORDS | Economic psychology, credit analysis, credit risk, credit scoring, application scoring.

\section{RESUMO}

O objetivo deste estudo é investigar a contribuição de variáveis psicológicas e de escalas sugeridas pela Psicologia Econômica na previsão da inadimplência de pessoas físicas. Portanto, uma amostra de 555 indivíduos completou um questionário de autopreenchimento. Ao adotar a metodologia de análise de regressão logística, as seguintes características psicológicas e comportamentais foram encontradas e associadas ao grupo de indivíduos em situação de inadimplência: a) dimensões negativas relacionadas com dinheiro (sofrimento, desigualdade e conflito); b) altas pontuações na escala de autoeficácia, provavelmente indicando um maior grau de otimismo e excesso de confiança; c) compradores classificados como compulsivos; d) indivíduos que consideram necessário dar presentes aos filhos e amigos, em datas especiais, mesmo que muitas pessoas considerem isso como sendo um luxo; e) problemas de autocontrole, identificados por pessoas que bebem, em média, mais de quatro copos de bebida alcoólica por dia.

\section{PABLO ROGERS}

pablo.rogers@hotmail.com Professor at Universidade Federal de Uberlândia, Faculdade de Gestão e Negócios - Uberlândia Minas Gerais, Brazil

\section{DANY ROGERS}

danyrogers@yahoo.com.br Professor at Universidade Federal de Uberlândia, Faculdade de Ciências Integradas do Pontal - Uberlândia Minas Gerais, Brazil

\section{JOSÉ ROBERTO SECURATO}

securato@usp.br

Professor at Universidade de São

Paulo, Faculdade de Economia, Administração e Contabilidade São Paulo - SP, Brazil
PALAVRAS-CHAVE / Psicologia econômica, análise de crédito, risco de crédito, credit scoring, application scoring.

\section{RESUMEN}

El objetivo de este estudio es investigar la contribución de variables psicológicas y escalas, sugeridas por la Psicología Económica, en la previsión del incumplimiento de personas físicas. Por lo tanto, una muestra de 555 individuos llenó un cuestionario que se autocompletaba, compuesto por variables psicológicas y escalas. Al adoptar la metodología de análisis de regresión logística, las siguientes características psicológicas y comportamentales fueron encontradas, asociadas con el grupo de individuos en situación de incumplimiento: a) dimensiones negativas relacionadas con el dinero (sufrimiento, desigualdad y conflicto); b) altas puntuaciones en la escala de autoeficacia, probablemente indicando un mayor grado de optimismo y exceso de confianza; c) compradores, clasificados como compulsivos; d) individuos que consideran necesario hacer regalos a sus hijos y amigos, en fechas especiales, aunque muchas personas consideren eso como un lujo; e) problemas de autocontrol, identificados por personas que beben, en promedio, más de cuatro copas de bebida alcohólica por día.

PALABRAS CLAVE I Psicología Económica, análisis de crédito, riesgo de crédito, credit scoring, application scoring. 


\section{INTRODUCTION}

Economic Psychology addresses the day-to-day issues in people's lives, such as employment, unemployment, processes and decisions regarding purchases, savings, investments, debt, taxes, betting and response to advertising. A recent ramification of Economic Psychology and Behavioral Economics that has gained prominence in the international academic environment is known as Behavioral Finance (Ferreira, 2008). The content of Behavioral Finance includes the study of the behavior of financial markets, including psychological aspects in the analysis, and broadening the traditional economic perspective, which fails to explain relevant changes and deviations (anomalies) in financial markets.

Issues involving credit or debt have been widely investigated by economic psychologists (Boddington \& Kemp, 1999, Davies \& Lea, 1995, Gardarsdóttir \& Dittmar, 2012, Gathergood, 2012, Kim \& Devaney, 2001, Lea, Webley \& Levine, 1993, Lea, Webley \& Walker, 1995, Livingstone \& Lunt, 1992, Mewse, Lea \& Wrapson, 2010, Norvilitis \& MacLean, 2010, Norvilitis et al., 2006, Norvilitis, Szablicki \& Wilson, 2003, Perry, 2008, Pirog III \& Roberts, 2007, Roberts \& Jones, 2001, Seaward \& Kemp, 2000, Stone \& Maury, 2006, Tokunaga, 1993, Vio, 2008, Wang, Lu \& Malhotra, 2011, Webley \& Nyhus, 2001) aiming to understand the psychological profile, especially from the behavioral standpoint, of individuals who are more likely to take loans, become indebted and have debt problems. Besides the demographic variables, these studies (ibid.) have considered factors related to attitudes involving money, self-efficacy, locus of control, optimism, self-esteem, compulsive behavior, attitudes involving debt and credit, self-control, consumer behavior, economic socialization, financial education, social comparison, time horizon, materialism and financial well-being. In this context, the studies and variables attempted to explain why some individuals have problems with debt/credit while others do not, even when they have similar economic conditions.

This paper aims to investigate some psychological variables and to identify the key determinants in the construction of a scoring model for individual entities. As a result, from the credit analyst's point of view, in addition to testing variables commonly used in credit scoring models for individual entities - especially those related to the payee's sociodemographic profile - this study evaluates the psychological variables and scales suggested by Economic Psychology using an application-scoring model specifically created for this purpose.

The results suggest that the meaning of money scale, self-efficacy scale, compulsive buying scales, some variables of self-control and consumer behavior are capable of explaining the status of individual defaults, even after having controlled the influence of sociodemographic and situational factors.

\section{METHODOLOGY}

\section{Data collection}

The variables presented in the model to be tested were obtained from a self-completion questionnaire with approximately 200 items to be answered, distributed in seven pages (the estimated time to complete the survey was between 25 to 30 minutes). No financial incentive or any kind of payment was given to the participants. The study explicitly required the identification of the respondent (Name and Taxpayer Enrollment), even though it was made clear to all participants that they were involved in an academic research and the confidentiality of any information provided would be upheld. In addition, the respondents were asked not to leave any question unanswered. Finally, they were advised there would be no right or wrong answers, because the researchers were interested in the individual's point of view, especially in those questions aimed to identify the respondents' psychological profile.

We adopted the following strategy for applying the study questionnaire:

- Validation of the questionnaire: throughout 2009 a total of 280 questionnaires were applied to: a) undergraduate and graduate (MBA) students from the Universidade Federal de Uberlândia; b) workers from an average size cleaning product company and a large food company, both located in Uberlândia, Minas Gerais/Brazil; and c) people (friends and family) related to the researchers. Once the questionnaires were collected, it was possible to develop its final version. The adjustments included grammatical corrections; semantic changes of words and phrases; exclusion of items and scales; and inclusion of items and scales. The initial version of the questionnaire included an overconfidence instrument. However, due to its length and the fact that the overconfidence construct was strongly related to optimism, self-efficacy and self-esteem, we opted to exclude this instrument. Moreover, the original version did not include the compulsive 
shopping scale, since we became aware of this after the initial studies that generated the pilot questionnaire. We also decided to replace some questions on the questionnaire in order to identify the self-control/illusion of control by the proxies suggested by Webley and Nyhus (2001) and Vio (2008) and to reduce the size of the questionnaire.

- $\quad$ Final questionnaire: Instituto Verità - a company with over 15 years of experience conducting field research, applied the final version of the questionnaire to a sample population in Uberlandia, Minas Gerais/Brazil. A total of 975 questionnaires were applied between February and April of 2010. At the end of April, the CPFs (Taxpayer ID no.) of individuals in the sample were surveyed in the SCPC Brasil (Serviço Central de Proteção ao Crédito) and Serasa Experian databases.

After consulting the SCPC Brasil and Serasa Experian database, 128 individuals were eliminated from the sample because their taxpayer enrollments were listed as invalid. As a result, the model developed in this research was based on a sample of 847 individuals $(70 \%$ for the development sample and $30 \%$ for the test sample).

\section{Description of variables}

\section{Credit risk}

Through the individuals' taxpayer enrollment, it was possible to identify the number of financial constraints in the SCPC Brasil and Serasa Experian databases. If the individual had at least two financial constraints, the individual was considered to have bad credit (CRED variable $=0$ ). Otherwise, the individual was considered to have good credit (CRED variable $=1$ ). The CRED binary variable was used as the dependent variable of the model tested in order to measure individuals' credit risk.

\section{Sociodemographic variables}

For this class of independent variables, we listed some registration data commonly used in application scoring models (Sicsú, 2010, Thomas, Eldman \& Crook, 2002), as indicated in Table 1.
TABLE 1. Sociodemographic variables

\begin{tabular}{|c|c|}
\hline VARIABLE & DESCRIPTION \\
\hline AGE & Age (years) \\
\hline MALE & Gender (male or female) \\
\hline FROM & State of origin (birth) \\
\hline SCHOOL & Level of education \\
\hline MARITAL & Marital Status \\
\hline NPEOPLE & Number of people living in house \\
\hline FINANCIALDEP & Number of financial dependents \\
\hline RESTATUS & Status of the residence (own or not) \\
\hline SCHOOLSPOUSE & Level of education of spouse \\
\hline RETYPE & Type of property (house, apartment, etc.) \\
\hline RETIME & Period (years) living in the residence \\
\hline JOB & Current occupation (job) \\
\hline JOBTIME & Period in the occupation stated \\
\hline JOBSPOUSE & Occupation of spouse \\
\hline INCOME & Gross monthly income \\
\hline INCOMESPOUSE & Gross monthly income of spouse \\
\hline INCOMEFAMILY & Gross monthly income of family \\
\hline NVEHICLES & Number of vehicles owned \\
\hline VRVEHICLES & Estimated value of the vehicles stated \\
\hline PROPERTY & Number of properties \\
\hline VRPROPERTY & Estimated value of the properties stated \\
\hline INVESTMENTS & Existence of financial investments \\
\hline
\end{tabular}

\section{Situational variables}

Based on a scale developed by Davies and Lea (1995), we included two questions in the set of independent variables, whose purpose was to control the influence of psychological socio-demographic variables: 1) CREDITCARD = How many credit cards do you have?; and 2) What events happened to you over the past three months? The options to answer this last question were: $\mathrm{EVENT}_{1}=$ health problems or serious accident in the family; EVENT2 = birth or adoption of children; EVENT3 = unemployment; EVENT4 = unexpected situation that caused serious financial difficulties; EVENT5 = separation or divorce; EVENT = no important event that could affect my "lifestyle". In this case, six dummies variables were constructed: $(=1)$ if the answer to the events variables was affirmative.

\section{Psychological scales}

Based on studies in the field of Economic Psychology that related personality/behavior traits with credit or debt, we initially 
sought to list nationally validated and widely used psychometric scales that could explain the customer's credit risk. The strategy used covered the following steps:

1. Survey in papers addressing Economic Psychology, mainly international scientific papers, covering the most widely used psychological scales;

2. Survey in national Psychology papers to discover whether the psychological scale listed in the previous step was nationally validated, even within a context different than the one intended in this study;

3. If the same, nationally validated, psychological scale of step 1 was not found, we surveyed a similar psychological scale, seeking to measure the same psychological construct, albeit in a different context than the one intended with this study.

After this process, we selected six psychological scales: 1) Meaning of Money Scale (MMS), based on Moreira (2000); 2) General Self-Efficacy Scale of Schwarzer (1992); 3) Locus of Control Scale of Lenvenson, according to the validation of Dela Coleta and Dela Coleta (1997); 4) Life Orientation Test (LOT), originally proposed by Scheier, Carver and Bridges (1994), to measure the construct Optimism; 5) Rosenberg Self-Esteem Scale, validated nationally by Avanci, Assis, dos Santos and Oliveira (2007); and 6) Compulsive Buying Scale of Faber and O'Guinn (1992).

The extraction of the factors from the scales and the operationalization of each variable tested in the research model can be found in Table 2. The same frame also presents the reliability of each factor/variable (Cronbach's a) from our data, and the references that justified each of the constructs in our model, according to the three steps outlined above.

\section{Psychological and behavioral variables}

The psychological and behavioral variables represent specific questions included in the questionnaire, according to the procedures adopted by Livingstone and Lunt (1992), Lea et al., (1995), Hayhoe, Leach and Turner (1999), Webley and Nyhus (2001) and Vio (2008). The overall goal is to analyze the influence of social comparison, financial education, consumer behavior and self-control in credit risk. Table 3 summarizes these variables.

\section{RESULTS}

Since it refers to a binary dependent variable, we adopted the logistic regression statistical procedure to build the model, in accordance with Thomas et al., (2002) and Sicsú (2010). Essentially, we sought to simulate the construction of a credit-scoring model, including psychological variables and scales. The model endeavors to generate information that will contribute to decide whether to approve or deny a new credit application based on assessing the risk that a customer holds. Thus, we could argue that the model tested is presented as a generic credit scoring model to be applied in new customer applications - application scoring (Sicsú, 2010, Thomas et al., 2002).

After collecting the data and structuring the basis for developing the study, we employed all the operational procedures for building a credit-scoring model through: a) verification of whether the data was properly collected; b) analysis of the characteristics of each variable individually; and c) study of the relationship between variables. Specifically, before determining the final model to be tested, the potential variables chosen were analyzed and addressed: i) identification of possible inconsistencies; ii) analysis of missing cases; iii) detection of the presence of outliers; iv) individual comparison of the variables with the group of good and bad credits; v) redefinition of some variables and creation of other variables (dummies and merging of categories).

After performing the operating procedures described above, 555 observations and 96 variables remained in the sample. The remaining variables were distributed as: a) 55 sociodemographic variables; b) six situational variables; c) 25 variables were based on psychological scales; and d) 10 were psychological and behavioral variables. At this point, we applied the backward elimination method for selecting variables. So, we initially listed all variables for the final model, but the non-significant variables were gradually eliminated. The variables were excluded, one by one, up to the point that the exclusion of any variable compromised the discriminating power of the final model, considering $10 \%$ of significance for the variable to be added or excluded from the model, according to Wald's statistics/criteria.

The final model is shown in Table 4, and its adjustment statistics in Table 5. The final model indicated 27 significant variables. Nonetheless, it only requires the information of 21 variables to build the scoring formula. The statistical adjustments of the model in the development sample are: 1) Hosmer and Lemes show Test equal to 7.985 ( $p$-value $=0.435) ; 2$ ) $R^{2}$ of Cox and Snell equal to 0.32 ; 3) $R^{2}$ of Nagelkerke equal to 0.495 ; and 4) Count $R^{2}$ equal to 0.714 . The values of KS and the ROC curve were, respectively, $50.8 \%$ and 0.809 , considered excellent in the market practice, especially when applied to a scoring model. The final model classification table (Table 6) indicates a loss to predict good and bad credits correctly in the test sample, with marginal reduction in the hit rate, without, invalidating the proper adjustment of the model. On the contrary, a hit rate of $76.3 \%$ is excellent when it refers to application scoring models. 


\section{TABLE 2. Psychological scales and source concept}

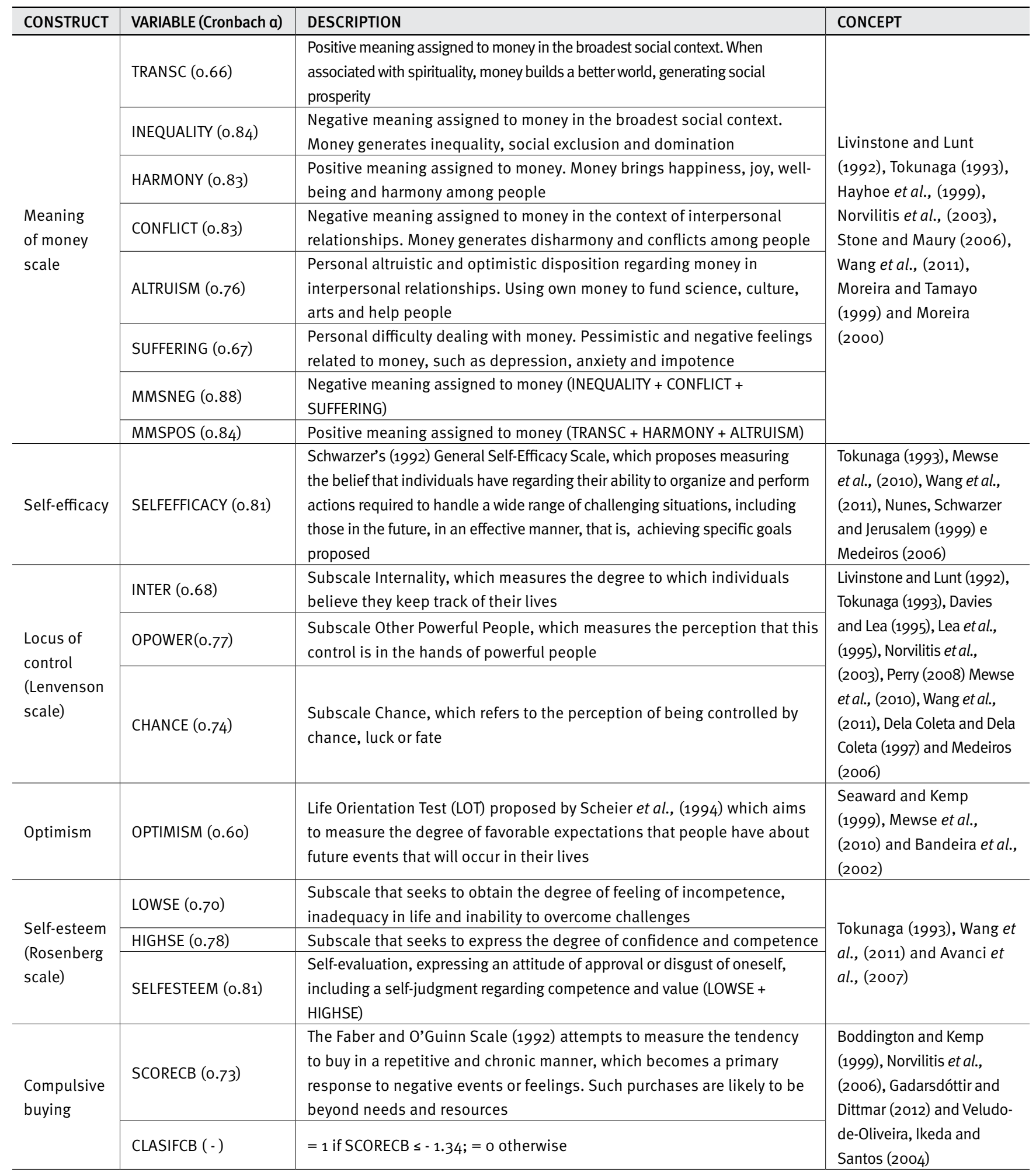

Note: This table shows the psychological scales used in the study. The VARIABLE column indicates the factors extracted from the scales, which became independent variables in the final model: the values in brackets indicate Cronbach's alpha of the factor/variable from the survey data, and allow us to conclude that all factors have good or acceptable reliability, except for the variable OPTIMISM. In the column DESCRIPTION, we sought to evidence a succinct concept of the factor or operationalization of the variable, if it comes from another factor, as is the case of the variables MMSNEG, MMSPOS, SELFESTEEM and CLASIFCB. With regard to the concept, we sought to describe the bibliographies in the field of Economic Psychology, which specifically addressed credit or debt, and used the construct in question in their studies. The bibliographies highlighted in bold indicate that the study used the same scale as this research. We used references that used and/or validated the scale in Brazil, even in a context different from the business or credit field, because until that moment we had found no studies that had conducted this approach nationally. 


\section{TABLE 3. Psychological and behavioral variables}

\begin{tabular}{|c|c|c|}
\hline ANSWER & VARIABLE & DESCRIPTION OF QUESTIONS \\
\hline \multirow{6}{*}{$\begin{array}{l}\text { Social } \\
\text { comparison } \\
\left(Y_{e s}=1 ; \mathrm{No}=0\right)\end{array}$} & $\mathrm{SC}_{1}$ & I think I have less money than my friends \\
\hline & $\mathrm{SC} 2$ & I think I have less money than my relatives \\
\hline & $\mathrm{SC}_{3}$ & I think I have less money than my coworkers \\
\hline & $\mathrm{SC}_{4}$ & I think I have less money than the people I see on TV and it BOTHERS me \\
\hline & $\mathrm{SC}_{5}$ & I think I have less money than the people I see on TV, but it DOES NOT BOTHER me \\
\hline & SOCIALCOMP & $\mathrm{SC}_{1}+\mathrm{SC}_{2}+\mathrm{SC}_{3}+\mathrm{SC}_{4}+\mathrm{SC}_{5} *$ \\
\hline \multirow{5}{*}{$\begin{array}{l}\text { Financial } \\
\text { education } \\
\left(Y_{e s}=1 ; \mathrm{No}=0\right)\end{array}$} & $\mathrm{FE} 1$ & Have you ever attended any personal finance course? \\
\hline & FE2 & Have you ever borrowed money from relatives or friends? \\
\hline & FE3 & Do you make a list before you go shopping? \\
\hline & FE4 & Do you have a personal budget, where you try to list all your expenses and income? \\
\hline & FINANCIALED & $\mathrm{FE}_{1}+\mathrm{FE}_{2}{ }^{*}+\mathrm{FE}_{3}+\mathrm{FE}_{4}$ \\
\hline \multirow{5}{*}{$\begin{array}{l}\text { Consumer } \\
\text { behavior } \\
(\text { Necessity=1; } \\
\text { Luxury=0) }\end{array}$} & $\mathrm{CB} 13$ & Give gifts to friends on special dates \\
\hline & CB14 & Give gifts to relatives on special dates \\
\hline & CB15 & Give gifts to children on special dates \\
\hline & $\mathrm{CB} 16$ & Celebrate special dates \\
\hline & NECESSITY & $\begin{array}{l}\text { Sum of answers to } 16 \text { consumer items, such as: DVD, refrigerator, internet, mobile phone, } \\
\text { etc..; for which answers were scored } 1 \text { if the respondent considers the item as a necessity or o } \\
\text { if considered a luxury. }\end{array}$ \\
\hline \multirow{2}{*}{$\begin{array}{l}\text { Self-control } \\
(\mathrm{Yes}=1 ; \mathrm{No}=0)\end{array}$} & DRINK & On average, do you drink more than 4 glasses of alcoholic beverage in a day? \\
\hline & SMOKE & Do you smoke cigarettes? \\
\hline
\end{tabular}

*Items must be inverted.

TABLE 4. Formula scoring of the final model

\begin{tabular}{|c|c|c|c|c|c|}
\hline Variables & B & S.E. & Wald & Sig. & ME (\%) \\
\hline $\begin{array}{l}\text { MARITAL } \\
\text { consensual union }\end{array}$ & -1.090 & 0.528 & 4.258 & 0.039 & -20.83 \\
\hline NPEOPLE & -0.264 & 0.116 & 5.145 & 0.023 & -5.44 \\
\hline $\begin{array}{l}\text { RESTATUS } \\
\text { rent }\end{array}$ & -1.027 & 0.318 & 10.447 & 0.001 & -16.82 \\
\hline $\begin{array}{l}\text { SCHOOLSPOUSE } \\
\text { incomplete high school }\end{array}$ & -1.018 & 0.588 & 2.996 & 0.083 & $-19 \cdot 39$ \\
\hline $\begin{array}{l}\text { JOBSPOUSE } \\
\text { freelance }\end{array}$ & 1.555 & 0.637 & $5 \cdot 960$ & 0.015 & 15.00 \\
\hline $\begin{array}{l}\text { INCOMESPOUSE } \\
\text { between } 600 \text { and } 1.000 \text { reais }\end{array}$ & -0.893 & 0.463 & 3.715 & 0.054 & -16.26 \\
\hline $\begin{array}{l}\text { INCOMESPOUSE } \\
\text { between } 2,000 \text { and } 3,000 \text { reais }\end{array}$ & -1.587 & 0.800 & 3.936 & 0.047 & $-33 \cdot 40$ \\
\hline $\begin{array}{l}\text { INCOMEFAMILY } \\
\text { between } 1,000 \text { and } 1,200 \text { reais }\end{array}$ & -0.999 & 0.422 & 5.612 & 0.018 & -18.34 \\
\hline CREDITCARD & 0.380 & 0.197 & 3.735 & 0.053 & 7.82 \\
\hline EVENT4 & -1.001 & 0.440 & 5.181 & 0.023 & -18.49 \\
\hline INEQUALITY & 0.094 & 0.026 & 12.972 & 0.000 & 1.94 \\
\hline
\end{tabular}


TABLE 4. Formula scoring of the final model

\begin{tabular}{|c|c|c|c|c|c|}
\hline Variables & B & S.E. & Wald & Sig. & ME (\%) \\
\hline $\begin{array}{l}\text { SUFFERING } \\
\text { score between } 17 \text { and } 19\end{array}$ & 2.497 & 0.805 & 9.618 & 0.002 & 20.56 \\
\hline $\begin{array}{l}\text { MMSNEG } \\
\text { score higher than } 126\end{array}$ & -2.128 & 0.956 & 4.955 & 0.026 & -45.03 \\
\hline $\begin{array}{l}\text { MMSNEG } \\
\text { score between } 105 \text { and } 126\end{array}$ & -1.638 & 0.592 & 7.646 & 0.006 & -26.79 \\
\hline $\begin{array}{l}\text { MMSNEG } \\
\text { score between } 95 \text { and } 104.99\end{array}$ & -1.765 & 0.529 & 11.107 & 0.001 & -34.66 \\
\hline $\begin{array}{l}\text { SELFEFFICACY } \\
\text { score between } 29 \text { and } 31.99\end{array}$ & -1.340 & 0.442 & 9.203 & 0.002 & -24.87 \\
\hline $\begin{array}{l}\text { SELFEFFICACY } \\
\text { score between } 28 \text { and } 28.99\end{array}$ & -2.237 & 0.604 & 13.731 & 0.000 & -48.08 \\
\hline CLASIFCB & -1.846 & 0.457 & 16.329 & 0.000 & -37.94 \\
\hline CB13 & -1.033 & 0.408 & 6.404 & 0.011 & -16.85 \\
\hline CB15 & -1.137 & 0.381 & 8.890 & 0.003 & -16.45 \\
\hline NECESSITY & .175 & 0.063 & 7.734 & 0.005 & 3.60 \\
\hline DRINK & -1.889 & 0.492 & 14.751 & 0.000 & -39.69 \\
\hline
\end{tabular}

Note: The resulting variables in the final model are explained in frames 1-3 and Section 2.2.3. When the variable, coded in uppercase, is accompanied, immediately below, by lowercase letters, it means that it is a dummy variable with the category in evidence - generated by the application of the CHAID method (Chi-squared Automatic Interaction Detection). ME represents the marginal effects in the mean of variables (typical individual of sample).

TABLE 5. Statistics of adjustment of the final model

\begin{tabular}{c|c|c|c|c|c}
\hline \multicolumn{3}{c|}{ Development Sample } & Test Sample & \multicolumn{2}{c}{ Total Sample } \\
\hline Cox Snell R & Nagelkerke R & Count R & Hit Rate & KS \\
\hline 0.320 & 0.459 & 0.814 & 0.763 & 0.508 & 0.809 \\
\hline
\end{tabular}

\section{TABLE 6. Classification of the final model}

\begin{tabular}{|c|c|c|c|c|c|c|c|c|}
\hline & & & \multicolumn{6}{|c|}{ Estimates } \\
\hline & \multicolumn{2}{|c|}{ Observed } & Bad credit & Good credit & $\%$ Correct & Bad credit & Good credit & $\%$ Correct \\
\hline \multirow{2}{*}{$\begin{array}{l}\text { Final } \\
\text { Model }\end{array}$} & $\begin{array}{l}\text { Credit } \\
\text { Classification }\end{array}$ & Bad credit & 45 & 63 & 41.7 & 10 & 34 & 22.7 \\
\hline & \multicolumn{2}{|l|}{$\%$ Total } & & & 81.4 & & & 76.3 \\
\hline
\end{tabular}

cut-off point $=0.34$ 
Before effectively testing the research hypothesis, the model used for this purpose proved very robust in several analyzes. Other models were estimated using different variable selection procedures (selection by blocks, forward selection and stepwise) with similar adjustments of Table 4 . In addition, since samples with 555 observations are considered small when developing credit scoring models, the model works better when applied to the development sample than when applied to the test sample. In this situation, Sicsú (2010) recommends the use of the bootstrap technique to estimate the classification table, which was used in the final model. The results of the bootstrap technique were similar to the ones found in Table 6.

\section{Research hypothesis test}

The scoring formula of the final model can be expressed as in the equation ('B' column of coefficients) of Table 4. The scoring formula is highly significant, with $\operatorname{LR}^{2}(27)=147.22$ ( $p$-value $=$ 0.000 ), so the coefficients of the model, on aggregate, are statistically different from zero. The verification of the core hypotheses of the work lies on testing whether the coefficients of psychological variables and scales in Table 4 are different from zero. The test of change in log of likelihood ratio (LR Test) produces LR $X^{2}(17)=105.175$ with a highly significant $p$-value (0.00o). Thus, as the core hypothesis of this work is not rejected, we may infer that some psychological variables and scales - controlled by sociodemographic and situational characteristics - contribute to forecasting the credit risk of individual entities.

Regardless of these findings, other analyses, not documented in this text for lack of space, corroborate the robustness of our conclusions. From the research data, five alternative models have been built using different variable selection techniques and showed similar scores and statistical adjustment, even tough, some carry different variables. In each model, the psychological variables and scales were statistically significant on aggregate. Another analysis lay on simulating three different default definitions (CRED variable) and building models from these definitions. Again, the psychological variables and scales were, on aggregate, highly significant. Additionally, the model in Table 4 showed high success rates, even considering the three alternative default definitions.

Other relevant information about the robustness of the model in Table 4 is that it produced credit risk scores statistically similar to those of the SCPC Score model. The SCPC Score is a product based on the credit scoring methodology of SCPC Brasil, which evaluates an inquired consumer's probability of default within the next 3 or 12 months. This generic application-scoring model of SCPC Brasil was computed using 6.8 million transactions/clients,
120 variables, more than 250 combinations of variables and produced a KS of $46 \%$. For each individual of the sample, on the same date when the credit information was obtained from SCPC Brasil, scores of the 12-month SCPC Score model were also collected in order to build the default variables. When computing the Spearman's correlation coefficient between the two scores (SCPC Score and final model), the value of 0.281 is found - which is highly significant at the level of $1 \%$. An additional interesting procedure lies on testing whether the score produces similar forecasts/ranks among the individuals. Thus, we considered the standardized value from the SCPC Score model and the scores of the model in Table 4 and applied the Wilcoxon's test for related samples. The same showed $z=$ -0.39 with $p$-value $=0.697$, leading us to not reject the hypothesis that the two scores produce similar ranks.

It is worth emphasizing that out of the total sample, 27.9\% of the individuals were ranked as bad credit and $72.1 \%$ as good credit. For these individuals, the rank of the SCPC Score results in approximately $29.9 \%$ of bad clients (high risk). The comparison between these two proportions justifies the failure to correct the value of the constant for the scoring formula or to weigh the observations for the sampling extracted from the calculations of the final probabilities, as recommended by Sicsú (2010). When working on samples of good and bad credits selected separately, the sizes of the two samples are generally not proportional to the percentages of good and bad credits in the population. However, in this situation, it seems the proportions of good and bad credits resulting from the definition of default are similar to the proportions of good and bad credits in the population.

\section{DISCUSSION OF RESULTS}

Amongst all variables listed, the variables (constructs) below were significant in the final model: 1) sociodemographic: status of residence (own or rented), marital status, spouse's education, number of people in the residence, occupation of the spouse, spouse's income and family income; 2) situational: number of credit cards and positive answer to the question about the occurrence of unexpected situations that caused serious financial difficulties; 3) psychological scales: Meaning of Money Scale (MMS), General Scale of Self-Efficacy and Compulsive Buying Scale; and 4) psychological and behavioral variables: self-control and consumer behavior. With respect to the sociodemographic and situational variables, coefficients presented signs that were expected, and were consistent with the economic status of the individual. Since this evidence is consolidated in the credit field, we will not extend the discussion of these results. 
Although any conclusion can be considered speculative and exploratory, by the pioneering use of MMS for this purpose, the reading of Tokunaga (1993), Hayhoe et al., (1999), Roberts and Jones (2001), Norvilitis et al., (2003) and Stone and Maury (2006) allowed us to expect that negative dimensions related to money (CONFLICT, SUFFERING, INEQUALITY and MMSNEG) would be more associated with individuals with debt problems. The coefficients of the final model, to a certain extent, helped to corroborate this expectation. However, the coefficients of variables MMSPOS and INEQUALITY proved to be contrary to what was expected. Even though these variables may be excluded from the final model, we opted to keep them, since lower scores in the positive dimension of money (MMSPOS) in the good credit group is a fact for the sample. In addition, since the INEQUALITY variable is often correlated with the others of MMS, it may be incurring multicollinearity or interaction, which is not entirely negative if we are attempting to predict rather than explain. Since the exclusion of the INEQUALITY variable would be a speculation, due to the exploratory character of MMS in explaining the status of default of individuals, we decided to improve the prediction with its permanence.

Contreras, La Fuente, Fuentealba, García, and Soto (2006) argue that the misuse of credit and bad debt habits may be affected by a low sense of self-efficacy. Considering this perspective, one could expect that the SELFEFFICACY variable scores (General Scale of Self-Efficacy) in good credit were higher than those of bad credit, and the coefficients of the SELFEFFICA$C Y$ variables were positive. The SELFEFFICACY variable dummies were all negative and the good credit mean score was lower than the bad credit group. Nevertheless, it is important to mention that self-efficacy is defined as the belief that the individuals have regarding their ability to organize and perform actions and which are required to effectively handle a wide range of challenging situations, including the prospective ones, in order to achieve specific objectives. In short, it is the assessment made by individuals regarding their ability to perform a task within a certain area, or the judgment of their own competence or capabilities required to achieve the planned performance. Self-efficacy is strongly related to other constructs, including self-esteem, locus of control, overconfidence and optimism (Bandeira, Bekou, Lott, Teixeira \& Rocha, 2002). Among the scales of these constructs, the Spearman correlation coefficients, based on the available data, were highly significant and presented the direction expected.

Specifically, it is worth judging the relationship presented between the self-efficacy scale and the construct optimism (Life Orientation Test - TOV). A positive relationship was con- firmed (Spearman coefficient equal to 0.287 with a highly significant $p$-value at $1 \%$ ) between the variables SELFEFFICACY and OPTIMISM, which is justified because optimism is a judgment that leads people to believe that their future will be better and brighter than that of other people, perhaps precisely due to greater self-efficacy. However, with regard to credit, optimism can lead to comfortable expectations of future income and encourage individuals to consume in the present and run into debt to justify their purchases. The tendency to overestimate future income is positively related to an individual's current debt levels (Boddington \& Kemp, 1999, Seaward \& Kemp, 2000). Thus, we could expect a negative coefficient from OPTIMISM. Apparently, the SELFEFFICACY variable is capturing this information in the final model.

In the research data, we noticed a close relationship of compulsive shopping with individuals' credit status, which was confirmed by the strong relationship between the classification of compulsive buyer (variable CLASIFCB), given by the scale of Faber and O'Guinn (1992), and the CRED variable. In addition, the CLASIFCB variable, placed with the other variables in the models, proved highly significant and in line with expectations. The fact that an individual is classified as a compulsive buyer reduces the likelihood of becoming a good credit (marginal effect) by $37.94 \%$.

In relation to consumer behavior, the results of the final model are consistent with Lea et al., (1995). Individuals who consider giving gifts to children and friends on special dates as a necessity, even though many people consider this a luxury, have a higher chance of being in the bad credit group. Therefore, inappropriate consumer behavior may help predict the individual's default status. Nonetheless, when analyzing the coefficient of the NECESSITY variable, which denotes the number of items (of the 16 items listed) classified as the individual's need, there is a positive relationship with good credit. This finding is not opposed to Lea et al., (1995) and Livingstone and Lunt (1992), because the NECESSITY variable may be related to information concerning economic status, which was confirmed by the positive and significant correlation between the NECESSITY variables and family income.

Problems of self-control, identified by the variable DRINK were important to identify individuals with a tendency towards major debt problems. The signs of the coefficients were as expected and indicated that people with low self-control: those who drink, on average, more than four glasses of alcoholic beverage are more likely to be classified as bad credit. Therefore, the results are consistent with those of Webley and Nyhus (2001) and Vio (2008). 


\section{Limitation of the findings}

The purpose of a credit-scoring model, which considers psychological variables and/or scales, should be carefully analyzed, even though the outcomes proved to be robust. This is related to the fact that there are practical, behavioral and legal arguments associated to the inclusion of these types of variables and methodological limitations of the research.

Considering the psychological scales on an application form for new clients, this would significantly increase the quantity of items that the applicant for credit should meet. The money meaning scale alone, for instance, requires 60 answer items. Companies that grant credit to consumers daily face a large number of requests that require largely automated instruments to help in credit-related decision-making processes. In addition to this, the data input needs to be verifiable. The data collected about the psychological variables do not hold these characteristics. Including questions that aim to collect data about the psychological variables may be highly complicated and burdensome for companies, and the veracity of the answers would be uncontrollable in their majority. If facing questions like "How many glasses of alcoholic drink do you drink per day?', consumers may quickly learn what to answer, as, over time, they conclude that a negative answer to this questions results in a positive credit-related decision, whereas this problem might not have existed with the data collected for the purposes of this study. In the research, we expressly guaranteed to study participants that their answers would be treated as fully confidential and would only serve to obtain a better understanding of the decision-making processes, in opposition to the data collected by companies as part of the credit analysis in which the participants are considered eligible or not eligible to receive credit.

Another important implication of behavioral nature, more strictly related to the above, refers to the change in the posture of the answers if the individuals face questions in a real credit borrowing situation. The structured credit imposed on individuals does not expressly mention the real reason for the research, and, thus, the following question is raised: Is it possible that, when filling out an application form, the purpose of which is to obtain credit from a company, the individual would answer it as he/she answered the questionnaire of this study?

In particular, some information that can be relatively easy to be verified by companies, such as statements of income, tax incomes, address, employment stability, etc., cannot be verified in a field study, in which the participants do not need to prove the information entered in the questionnaire. Thus, the "cheating incentive', when answering these questions, is higher when filling out a new application form to a new credit when com- pared to filling out a questionnaire to participate in an academic study. This discussion is broad and involves issues such as the limitations of psychological and experimental methods as a scientific method, especially self-completion questionnaires without incentive.

We emphasize that the legal and ethical implications of our findings should still be thoroughly debated. Given one of the primary discussions in this study, which is improving the existing credit scoring models, the information that companies are authorized to use, according to legislation in force (whether national legislation, comparisons or international agreements), should still be evaluated. For example, although academic literature suggests a relation between quality of credit and gender, race, religion or age in the United States of America, banks are not authorized to use this information in credit scoring models (Thomas et al., 2002). Making questions related to health problems (considering the use of alcohol as a chemical dependence, for instance) may be prohibited by law or, at least, questionable from the professional ethics point of view. Some psychologists may condemn the use of the psychological scales evaluated in this study for business purposes. In any case, the concern should lie on including information in the credit scoring models that companies will be authorized to use, from a legal and ethical point of view.

Lastly, we do not believe that including psychological factors in credit scoring models may alone solve problems of the companies that grant credit to consumers, with respect to the increase in credit risk and difficulty in defining its influences. The psychological variables may experience the same effect as the socioeconomic variables, which are already included in the credit scoring models: as the past observation of ability of payment (income and other debts) may change, with future changes in the economy (for instance, the beginning of a recession), past standards of behavior may also change (for instance, a person can cease to be alcohol-addicted).

In other words, a problem in applying credit-scoring models is that the information collected only provides an instantaneous status of someone's credit condition, whereas the credit grantor would like to base its decisions on an information flow. The current research only approaches this problem with the development of scoring models, adding psychological variables and scales to them, without exhausting the question whether psychological aspects are more or less changeable than sociodemographic aspects, exposed in the same institutional environment.

Still regarding the limitation of the findings, the barriers imposed on the empirical part of the work, such as the sample size used in statistical tests and the fact that this sample is a 
convenience sample, restrict wider inferences due to the availability of information required for strong conclusions. Despite this, we consider that the research is the first step in the credit analysis of the Brazilian consumer to understand theoretically the credit risk theme from a Behavioral Finance point of view, especially to explain credit risk by means of psychological variables and scales.

\section{CONCLUDING REMARKS}

The literature addressing credit in Brazil, within the area of finance, has been focusing on the discussion of models for credit portfolios: progress and applicability in the national sphere, and on the comparison of techniques for developing credit-scoring models. Specifically, with respect to credit-scoring models, it is believed that the concern about techniques for estimating credit-scoring models has been exacerbated and become misplaced, as studies have shown that no technique is superior to another to further improve the predictive power of the models. Thus, the natural progress should be in the search for new variables to be included in the credit-scoring models, since the performance of the models depends much more on the variables considered than the technique used.

The main point of this study was to evaluate whether some psychological variables, found in the literature on Economic Psychology can contribute to the analysis of individuals' credit risk, as they enhance the predictive power of the application scoring models.

Based on the methodology adopted, which basically simulated the construction of application scoring models by an experienced credit professional, our results suggest that the meaning of money scale, self-efficacy scale, compulsive buying scales, some variables of self-control and consumer behavior are able to explain the status of default of individuals, even after having controlled the influence of sociodemographic and situational factors.

The contributions arising from the results of this research may be discussed in the theoretical and practical field. In the theoretical field, the understanding of individual entities' credit risk was improved, as it raises variables that may increase the accuracy of the forecast of credit-scoring models. Based on the outcomes of this research, we consider that this first attempt in the Brazilian consumer credit market: a) established and developed a systemic study of the psychological credit risk behavior; b) enabled the identification of variables existing in the interrelation between Financial Management and Psychology; c) debated sources that may encourage other investigations to build credit scoring models; and d) compared the implications of increasing credit scoring models on a psychological basis.

From the Financial Management point of view, we have advanced when compared to the studies of Economic Psychology, as these researches were not developed from the credit analyst's point of view, but from researchers' points of view, which in majority were concerned about the social, economic and psychological matters resulting from the population's indebtedness. Additionally, a large part of these studies was developed using graduate students or based on situations of credit card debts.

In practical terms, some findings are immediately applicable. Some of the significant variables in the final model should be asked in the application form for new customers, such as: Do you consider giving gifts to friends on special dates a necessity or luxury? Do you consider giving gifts to children on special dates a necessity or luxury? On average, do you drink more than 4 glasses of alcoholic beverage a day? The limitation of this procedure was discussed in section Limitation of the findings.

It is worth mentioning that the variables considered in the study for the construction of the application-scoring model do not necessarily need to be used neither for these models nor for individuals only. A company that wishes to review/ build its behavioral scoring model could also use the psychological variables. Obviously, the permanence of these variables should be analyzed according to their predictive contribution to the final model. From another perspective, the variables analyzed could also be listed in corporate entity models, especially for small and medium enterprises, whose information regarding managing partners is crucial to measure the credit risk of the corporate entity.

\section{REFERENCES}

Avanci, J., Assis, S., dos Santos, N., \& Oliveira, R. (2007). Adaptação transcultural de escala de auto-estima para adolescentes. Psicologia: Reflexão e Crítica, 20(3), 397-405.

Bandeira, M., Bekou, V., Lott, K., Teixeira, M., \& Rocha, S. (2002). Validação transcultural do Teste de Orientação da Vida (TOV-R). Estudos de Psicologia. 7(2), 251-258.

Boddington, L., \& Kemp, S. (1999). Student debt, attitudes towards debt, impulsive buying, and financial management. New Zealand Journal of Psychology, 28(2), 89-93.

Contreras, L., La Fuente, C., Fuentealba, J., García, A., \& Soto, M. (2006). Psicología del endeudamiento: una investigación teórica. Document prepared for the subject of Economic Psychology, dictated in the Universidad de la Frontera.

Davies, E., \& Lea, S. E. G. (1995). Student attitudes to student debt. Journal of Economic Psychology, North-Holland, 16(4), 663-679. 
Dela Coleta, M. F., \& Dela Coleta, J. A. (1997). Estudos sobre o locus de controle: uma amostra da pesquisa brasileira no período 1979-1995. Cadernos de Psicologia, 1, 135-141.

Faber, R. J., \& O’Guinn, T. C. (1992). A clinical screener for compulsive buying. Journal of ConsumerResearch, 13(3), 459-469.

Ferreira, V. R. de M. (2008). Psicologia econômica: estudo do comportamento econômico e da tomada de decisão. Rio de Janeiro: Elsevier.

Gardarsdóttir, R. B., \& Dittmar, H. (2012). The relationship of materialism to debt and financial well-being: the case of Iceland's perceived prosperity. Journal of Economic Psychology, 33(3), 471-481.

Gathergood, J. (2012). Self-control, financial literacy and consumer over-indebtedness. Journal of Economic Psychology, 33(3), 590-602.

Hayhoe, C., Leach, L., \& Turner, P. (1999). Discriminating the number of credit cards held by college students using credit and money attitudes. Journal of Economic Psychology, 20(6), 643-656.

Kim, H., \& Devaney, S. A. (2001). The determinants of outstanding balances among credit card revolvers. Association for Financial Counseling and Planning Education, 12(1), 67-78.

Lea, S. E. G, Webley, P., \& Levine, R. M. (1993). The Economic psychology of consumer debt. Journal of Economic Psychology, 14(1), 85-119.

Lea, S., Webley, P., \& Walker, C. (1995). Psychological factors in consumer debt: money management, economic socialization, and credit use. Journal of Economic Psychology, 16(4), 681-701.

Livingstone, S. M., \& Lunt, P. K. (1992). Predicting personal debt and debt repayment: psychology, social and economic determinants. Journal of EconomicPsychology, 13(1), 111-134.

Medeiros, A. L. B. (2006). Alfabetismo funcional em alunos do curso de Administração de Empresas e sua relação com a auto-eficácia e o auto-controle de suas atividades de aprendizagem. São Paulo. Master's dissertation - Programa de Pós-Graduação do Centro Universitário Nove de Julho.

Mewse, A., Lea, S., \& Wrapson, W. (2010). First steps out of debt: attitudes and social identity as predictors of contact by debtors with creditors. Journal of Economic Psychology, 31(6), 1021-1034.

Moreira, A., \& Tamayo, A. (1999). Escala de significado do dinheiro: desenvolvimento e validação. Psicologia: Teoria e Prática, 15(2), 93-105.

Moreira, A. (2000). Valores e dinheiros: um estudo transcultural das relações entre prioridades de valores e significado do dinheiro para indivíduos. Brasília, 2000. PhD thesis - Instituto de Psicologia da Universidade de Brasília.

Norvilitis, J., Szablicki, P., \& Wilson, S. (2003). Factors influencing levels of credit-card debt in college students. Journal of Applied Social Psychology, 33(5), 935-947.

Norvilitis, J., Osberg, T., Young, P., Merwin, M., Roehling, P., \& Kamas, M. (2006). Personality factors, money attitudes, financial knowledge, and credit-card debt in college students. Journal of Applied Social Psychology, 36(6), 1395-1413.

Norvilitis, J. M., \& MacLean, M. (2010). The role of parents in college students' financial behaviors and attitudes. Journal of Economic Psychology, 31(1), 55-63.
Nunes, R., Schwarzer, R., \& Jerusalem, M. (1999). A escala de auto-eficácia geral percepcionada. Retrieved on 06 July 2010 from http://userpage.fu-berlin.de/ health/auto.htm.

Perry, V. G. (2008). Giving credit where credit is due: the psychology of credit ratings. The Journal of Behavioral Finance, 9(1), 15-21.

Pirog III, S. F., \& Roberts, J. A. (2007). Personality and credit card misuse among college students: the mediating role of impulsiveness. Journal of Marketing Theory and Practice, 15(1), 65-77.

Roberts, J. A., \& Jones, E. (2001). Money attitudes, credit card use, and compulsive buying among American college students. The Journal of Consumer Affairs, 35(2), 213-240.

Scheier, M., Carver, C., \& Bridges, M. (1994). Distinguishing optimism from neuroticism (and trait anxiety, self-mastery, and self-esteem): a reevaluation of the Life Orientation Test. Journal of Personality and Social Psychology, 67(6), 1063-1078.

Schwarzer, R. (1992). Self-Efficacy as a Resource Factor in Stress Appraisal Processes. In: R. Schwarzer (Ed.), Self-efficacy: Thought control of Action. Washington, DC: Hemisphere. Retrieved on 06 July 2010 from http://chipts.ucla.edu/assessment/ Assessment_Instruments/Assessment_pdf_new/assess_gses_pdf.pdf.

Seaward, H. G., \& Kemp, S. (2000). Optimism bias and student debt. New Zealand Journal of Psychology, 29(1), 17-19.

Sicsú, A. L. (2010). Credit Scoring: desenvolvimento, implantação, acompanhamento. São Paulo: Blucher.

Stone, B., \& Maury, R. V. (2006). Indicators of personal financial debt using a multi-disciplinary behavioral model. Journal of Economic Psychology, 27(4), 543-556.

Thomas, L., Eldman, D., \& Crook, J. (2002). Credit scoring and its applications. Philadelphia: SIAM - Monographs on mathematical modeling and computation.

Tokunaga, H. (1993). The use and abuse of consumer credit: application of psychological theory and research. Journal of Economic Psychology, $14(2), 285-316$.

Veludo-de-Oliveira, T., Ikeda, A., \& Santos, R. (2004). Compra compulsiva e a influência do cartão de crédito. RAE-Revista de Administração de Empresas, 44(3), 89-99.

Vio, B. B. (2008). Credit beyond rationality. 2008. 56p. Dissertation of Master of Science - Advanced Study in Economic and Consumer Psychology of University of Exeter, Exeter.

Wang, L., Lu, W., \& Malhotra, N. (2011). Demographics, attitude, personality and credit card features correlate with credit card debit: a view from China. Journal of Economic Psychology, 32(1), 179-193.

Webley, P., \& Nyhus, E. K. (2001). Life-cicle and dispositional routes into problem debt. British Journal of Psychology, 92, 423-446. 